\title{
Financial Distress-Detection Model for Islamic Banks
}

\author{
H. Nurul Husna and R. Abdul Rahman
}

\begin{abstract}
Banks that are experiencing financial distress would also experience distress to influence the stakeholders about their performance. Thus, in order to gain the stakeholders' confidence, these banks tend to execute False Financial Statements (FFS) in their reporting. With the absence of the FFS, the users might act in contrast with the companies' goal. Literature has established that at any time Islamic Banks (IBs) have relatively more liquidity and are less risky when compared to Conventional Banks (CBs). However, it does not guarantee that IBs will not face a financial distress. To rectify this situation, this paper will discuss the "financial distress-detection model” specifically for IBs as an early FFS prevention method.
\end{abstract}

Index Terms-Financial distress, false financial statements, Islamic Banks, financial criminology.

\section{INTRODUCTION}

The theoretical literature on Islamic Banks (IBs) shows IBs to be more stable as compared to the Conventional Banks (CBs) [1]. However, like other CBs, some of the IBs are also experiencing financial distress. The distress might lead them to manipulate the accounts in accordance to their interests or in a worse scenario; to cease their operations. For example, Ihlas Finance House, an Islamic financial institution in Turkey was closed in 2001 due to liquidity problems and financial distress. Meanwhile, Faisal Islamic Bank ceased its operations in the UK for regulatory reasons. Similar situations have also been experienced by Bank Taqwa in Bahamas which was closed in 2001 (www.wikipedia.com).

False or fraudulent financial reporting is defined as "intentional or reckless misconduct, whether act or omission, that results in materially misleading financial statements. It may entail gross and deliberate distortion of corporate records and the misapplication of accounting principles". [2] It might influence their decision making capabilities. With the FFS, the users might act in contrast with the companies' goals.

Upon experiencing financial distress, these banks are expecting to be helped. The government or other external parties would normally help by way of bail out. Bail out is an act of giving capital to a bank in danger of failing in an

Manuscript received February 21, 2012; revised May 10, 2012..This work were supported by Kementerian Pengajian Tinggi (Centre of Excellence), Accounting Research Institute and Universiti Teknologi MARA.

H. N. Husna is with Faculty Business Management and Globalization, Limkokwing University of Creative Technology, Inovasi 1-1, Jalan Teknokrat 1/1, 63000 Cyberjaya, Selangor, Malaysia (email: nurul.haron@limkokwing.edu.my).

R. A. Rahman is with Accounting Research Institute, Universiti Teknologi MARA, Shah Alam 40450, Selangor, Malaysia (email: shidah@salam.uitm.edu.my). attempt to save it from bankruptcy, insolvency, or total liquidation and ruin; or to allow a failing entity to fail gracefully without spreading contagion. The recent updates have shown that many banks across the globe have been bailed out by the government. For instance, the Fortis Banks in Belgium and Luxembourg have been bailed out with US\$6.79billion by the Belgium government and US\$3.61billion by the Luxembourg government respectively (www.bloomberg.com). In addition, Commerzbank received US\$27.15billion from Germany and the Anglo Irish Bank received US\$1.95billion from Ireland (www.reuters.com). Meanwhile, the Erste Bank received US\$3.50 billion from Austria (www.forbes.com) and the KBC bank received US\$7.10billion from Belgium (www.fidelity.com)

In the mid-2008, Dubai Islamic Bank, Kuwait Finance House and al-Rajhi Bank in Saudi Arabia were severely affected upon the diminishing stocks of the bankers. In addition, the Islamic al-Hilal Bank in Abu Dhabi and Noor Islamic Bank of Dubai that had good liquidity were now affected as the Dubai government had faced a crisis and was bailed out by the Emirate of Abu Dhabi. In 1997, Malaysian banks were tremendously distressed when faced with a recession. Given the severity of the losses and to maintain integrity of public savings and the stability of the financial system, Bank Negara Malaysia had to implement a rescue scheme. Rather than to bail these banks out, six domestic financial groups were instructed to merge in order to survive the onslaught of a greater competition (www.mir.com.my)

These financial distressed banks especially the survivors might perform FFS in order to convince the shareholders and stakeholders. Thus, these users might act differently upon being misrepresented by the FFS. In order to prevent those financial distressed banks (including the IBs) to perform FFS, there is a need to have a detection model of these financial distressed banks. At an early stage of detection, the external auditor specifically would be able to zoom into the audit areas that should be focused on. Thus, models (indicators) to detect distressed IBs are deemed important.

The main features of IBs that make it different from the CBs are the elements of the Islamic law (Shari'ah). The Shari'ah has clearly indicated the prohibition of wrong means [3]. These wrong means can be extended to riba, bribery, money laundering and defaulted payment. Riba consist of 2 types; Riba al-fadl and riba al-nasi'ah. Both are prohibited. Shari'ah also prohibits the involvement in interest-based assets such as conventional bonds, speculative investments such as derivatives and specific prohibited industries such as the armaments industry. The speculative is referred to as Gharar (uncertainty).

Apart from the Central Banking Act, the IBs also need to 
comply with the Islamic Banking Act 1983 that requires them to have a Shari'ah Advisory Board (SAB). Under section $13 \mathrm{~A}$ of the Act, an IB is advised by the SAB and it must comply with the advice.

\section{ISLAMIC BANKING IN GENERAL AND IN MALAYSIA}

A combination of religious, economic, political and other historical factors have influenced the development of the structure of IBs [1]. Islamic Banking refers to a few available forms [4] such as:-

- Islamic windows: Islamic financial service and product outlets available within conventional financial institutions.

- Islamic subsidiaries: Islamic financial organisations whose parent company is often a conventional financial institution.

- Islamic financial institutions: Standalone financial institutions that focus solely on providing Islamic financial products and services

Before the intervention of IBs, customers especially those who were Muslims did not know specifically how the banking system was operated. The issues of Shari'ah in financial products lacked exposure. But, in the early 1970s, the customers, especially the Muslims originally in the Middle East, South East Asia and across the globe have become more alert to the Shari'ah requirements.

The earliest references to the reorganisation of banking on the basis of profit sharing rather than interest are found in [5]- [7] which are all around the late forties These researchers have proposed a banking system based on the concept of Mudharabha - profit and loss sharing. Subsequently, the pioneer of IB was introduced by the Dubai Islamic Bank in 1975. This institution has combined the best of the traditional Islamic values with technology and innovation that characterise the best of modern banking. Dubai Islamic Bank has established itself as the undisputed leader in its field, setting the standards for others to follow as the trend towards IBs gathers momentum in the Arab world and internationally. Gradually, the pioneer countries inventing in the IBs are Malaysia, Pakistan, Iran and Sudan.

In the past two decades, interest-free banking has attracted more attention, partly because of the political interest it created in Pakistan and partly because of the emergence of young Muslim economists. Work specifically devoted to this subject began to appear in this period. Subsequently, Islamic banking and finance is now one of the world's fastest-growing economic sectors that comprises more than 400 institutions with assets under management in excess of US\$ 1 trillion (US\$1,000 billion) (www.dib.ae/en/index.htm).

In understanding the principles of IBs, there are a few Shari'ah compliance and principles that need to be focused on. The principles are as follows [4]:-

- Application of interest rates prohibited: The concept of socioeconomic justice in Shari'ah law states that interest rates (riba) cannot be applied in loan situations; however, a rate of return is allowed in sale conditions.

- High transparency in financial disclosure: The restrictions on speculative behaviour indicate the need for a high degree of transparency and information disclosure by IBs in their transactions and operations. As a result, IBs keep separate accounts and ledgers for their Islamic operations and tend to provide separate Islamic financial reports.

- Asset-based financial system: In line with the limitations on speculative behaviour, Islamic financial transactions are based on an underlying asset, resulting in an asset-based financial system.

- Investment limitations: IBs are prohibited from investing in certain industries and face limitations in using certain types of financial products that conflict with Islamic principles. For example: investment in interest-based assets such as conventional bonds, speculative investments or Gharar (uncertainties such as derivatives and specific prohibited industries such as those involving armaments, alcohol production, casinos, pork and gambling related activities. .

- Focus on developmental and social goals;

- Subject to additional reviews by the Shari'ah Supervisory Board (SSB).

The main objective of the SSB is to give credibility to the operations of IBs by authenticating their legitimacy from the Shari'ah point-of-view [8]. The SSB would act as the control mechanism in ensuring Shari'ah compliance in all the activities of the IBs. In practice, IBs are not very different from CBs [9].To remain competitive, IBs have been innovative in their offering of products that do not violate Shari'ah but to a certain extent, they are still perceived as "Islamising" products and instruments of the capitalistic system rather than applying their own minds in developing products based on Islamic concepts [10]. The key difference is to ensure that the conventional products follow the Shari'ah law by "Islamising" them.

Despite the growing acceptance of IBs, there is still skepticism on the purity of the products offered and also the sincerity of those managing the IBs [10]. Thus, it can be noted that the Islamic financial products in the IBs must be compliant to the Shari'ah. Any non-compliance could cause the financial products of the IBs to no longer be Islamic. In addition, the membership of SSBs is often drawn from the professional specialist of Islamic jurisprudence [11]. The withdrawal could safeguard the interest of the customers in ensuring that their wealth and monetary transactions are in line with the Shari'ah requirement.

In addition, it is found that IBs are under the pressure of paying its investment depositors a rate of returns which is higher than what should be payable based on the actual performance of the funds. This is as a result of the competitive pressure to induce its investment account holders not to withdraw their funds from the bank and invest them elsewhere [12].

However, IBs have been proven to be able to stay competitive with other CBs [13] in which the IBs allocated a greater share of their assets to financing activities compared to the $\mathrm{CBs}$ and that they were also better capitalised. In addition, [13] also found that the profitability of the IBs significantly increased with market power, though this did not warrant higher profitability levels for the IBs.

Muslims in Malaysia have long been aware of the need for Islamic financial products that discourage interest or riba. They in fact have been searching for IBs in Malaysia 
that could fulfill their religious interests. With strong government support in which $30 \%$ of the paid up capital was provided by the Malaysian government., Bank Islam Malaysia Berhad (BIMB) was established in July 1983. The establishment was sought as the solution to the Muslims' dilemma in financial products. The establishment started with a paid-up capital of only RM80 million, which swelled to its current peak of RM1.73 billion as of June 2009. This significant growth has been due to the increase of the Islamic Financial Products through the implementation of its expansion programmes and asset growth (www.bankislam.com.my).

Subsequently, due to the vast demand, other CBs have started to move to provide Islamic Financial Products as well. Islamic banks in some other countries perform both commercial and investment banking services but do not establish firewall to separate these two services legally, financially and managerially [14]. Unlike Malaysia, both the local banks and foreign banks provide both Islamic and conventional products. They separate the two systems under one roof. The Islamic Banking would normally exist as an Islamic Subsidiary or Islamic Window of the CBs. Thus, Malaysia provides a dual banking system. Thus, it has become a unique setting to compare Islamic banking practices with those of conventional banking [9]. In addition, Malaysia, which is reported to have the largest IBs, capital, and insurance markets in the world (World Bank, 2006), is an ideal representative of IB practices in general [9]. Besides the Interest-free Banking Scheme, Malaysia has a well-developed Islamic interbank money market, Islamic government debt securities market, and Islamic insurance market.

There is no theoretically optimal system or standard textbook blueprint for the structure and process of regulating and supervising financial institutions, including banks [15]. However, in Malaysia these IBs are required to comply with the Islamic Banking Act 1983, Guidelines on the Management of Shari'ah Committee issued by Bank Negara Malaysia (BNM), Shari'ah Advisory Council (SAC) of BNM and the Securities Commission requirements. The statutory compliance requirement would beneficially protect the Muslims' interest in performing their halal daily monetary transactions.

The IBs have gradually contributed to the Malaysian economy. The Islamic Financial Products contributed 10\% to $11 \%$ on average to the total income of the $\mathrm{IBs}^{1}$. At the same time, the scale of the Islamic monetary operations was in line with the size of the IB system in Malaysia which has increased to $19.6 \%$ of the total assets of the banking system as of end-2009 (17.4\% as of end-2008) (www.bnm.com.my).

IBs are competing with each other and give extra attention in providing the Islamic Financial Products. These IBs have a follow-customer strategy, even if that means earning losses in a particular market [13]. They participate in the IBs' segment so that they could better serve their customers in this region and to stay competitive in the industry. However, in running their operations, the banks

\footnotetext{
${ }^{1}$ Of the country's nine listed banks in the third quarter ending Sept 30, and $9 \%$ in the second quarter.(The Star)
}

might have various problems including financial distress. This distress could lead them to various problems such as bankruptcy, collapse, and bailout and being merged and acquired.

\section{FINANCIAL DiSTRESSED BANKS}

Financial distressed banks can be defined as the condition of being in severe difficulties over money, especially being close to bankruptcy (www.qfinance.com). The difficulties come in whenever the banks cannot meet or have difficulty paying off its financial obligations to its creditors. The chance of financial distress increases when the banks have high fixed costs, illiquid assets, or revenues that are sensitive to economic downturns. Whenever the countries in which the banks are operated are having a recession, the banks would be highly exposed to financial risks, bank crises and even worse: bank failure, [16] who reviewed bank failure prediction methods have compiled various reasons of bank failures. Bank crises are more likely in countries with low GDP growth, high real interest rates, high inflation rates, and explicit deposit insurance system. Countries that are more susceptible to balance of payment crises also have a higher probability of experiencing banking crises [17], [18] found that banks with lower capitalisation, higher ratios of loans to assets, poor quality loan portfolios and lower earnings have higher risk of failure

US collapsed banks increased significantly in 2009 with a total of 72 as compared to only 25 collapsed banks in 2008 . In 2007, there were only three. These bank failures have highlighted the financial system's unresolved toxic asset crisis. An estimated US $\$ 2$ trillion in bad debt remains in the bank books, with banks refusing to write down or sell assets whose real worth is only a small fraction of their nominal value. Compounding the many problems of the banks is an ongoing contraction in economic activity, which in turn, is rebounding on the financial sector (www.wsws.org).

The Dubai markets are shrugging off Dubai's collapse in which the real estate prices have dropped by 50 percent $^{2}$; its projects stopped and thousands of workers were laid off. It has badly contributed to ramifications of a few banks. These banks are Bank of America, Goldman Sachs, Citigroup and some other insolvent bankers in which have been bailed out in 2009. These banks are seeking to delay debt payments and are negotiating for an extension of the debt maturities to stay alive. Dubai has accumulated US $\$ 80$ billion of debts by expanding in banking, real estate and transportation before credit markets seized up in 2008 (www.bloomberg.com).

According to financial analysts, in May 2010 Greece has received a total of EUR30.6 billion ${ }^{3}$ financing plan from International Monetary Fund (IMF), European Commission, Germany, France and Italy for the effort to rescue the

\footnotetext{
${ }^{2}$ from their 2008 peak, according to Deutsche Bank

${ }^{3}$ EUR5.5billion (US\$6.8billion) on $12^{\text {th }}$ May 2010 as the first part of the EUR20billion (US\$25billion) of the IMF's financing plan, followed by EUR14.5billion (US18billion) from the European Commission received on $18^{\text {th }}$ May, while Germany, France and Italy have also contributed EUR4.4 billion (US5.5 billion), EUR3.3 billion (US4 billion) and EUR2.9 billion (US3.6 billion) respectively - IFN Reports (www.islamicfinancenews.com)
} 
country that is having a financial distress. In this situation, financially distressed banks are also affected by the bailout (www.islamicfinancenews.com).

Banks operate in a highly regulated environment in that they are monitored by Central Banks and other regulatory agencies [19]. However, it does not prohibit a bank from conducting the FFS. By reporting the actual situation, the banks predict that the users might act in contrast with the banks' goals (to attract or retain the shareholders, or to pay more taxes). Through the FFS, the actual figures would be manipulated using the various FFS methods. Thus, FFS has been a preference for a bank to mislead the users' understanding regarding the bank performance and position.

Muslims are very particular in ensuring that all the business transactions are in accordance with the Shari'ah. However, very limited financial distressed models have been established specifically for IBs. The model is expected to be used by the auditors before beginning their audit by referring to the management's accounts figures. At this early stage, the distress situation would promote the IBs to perform earnings management. [20] defines earnings management as the intentional misstatement of earnings leading to bottom line numbers that would have been different in the absence of any manipulation. The bottom line could have been changed from profit to greater profit, profit to losses or from losses to greater losses. It is prohibited by Islam under Khata'l Misrepresentation and Ta'azir.

Thus, the auditors are expected to ensure the model is used throughout the audit process; then the published data in the annual reports would safeguard the users' interests.

\section{DETECTION MODELS OF FinANCIAL Distress FOR ISLAMIC BANKS}

It is found that there are many financial distress detection models for CBs. Unfortunately, there are not many studies on the detection being done specifically for IBs. However, the detection models for CBs could also be applied in IBs with some modification; by adding the Shari'ah compliance. The modification is needed as the main difference between the CBs and IBs is the Shari'ah compliance while the others are similar.

Most central banks have employed various early warning systems (EWS) to monitor the risk of banks for years. However, the repeated occurrence of banking crises during the past two decades - such as the Asian crisis, the Russian bank crisis, and the Brazilian bank crisis-indicates that safeguarding the banking system is not an easy task [16]. The EWS are able to supplement information obtained from on-site examinations and, in turn, help predict impending bank failures [21].

There are various detection models that have been constructed in CBs. [4] grouped the models into the following families of techniques: (i) statistical techniques, (ii) neural networks, (iii) case-based reasoning, (iv) decision trees, (iv) operational research, (v) evolutionary approaches, (vi) rough set based techniques, (vii) other techniques subsuming fuzzy logic, supporting vector machine and isotonic separation and (viii) soft computing subsuming seamless hybridisation of all the above-mentioned techniques. Based on these methods, various authors came out with various research findings, [22] found that stock market information can be used to estimate leading indicators of bank financial distress. Instead of focusing on bank failures or on severe financial distress, they considered the prediction of any downward change in the banks' financial health. There were 64 European banks selected. They used a logit econometric early warning model, designed for European banks, which tests if market based indicators add predictive value to models relying on accounting data. They also studied the robustness of the link between market information and financial downgrading in the light of the safety net and asymmetric information hypotheses. Some of their results supported the use of market-related indicators. Other results showed that the accuracy of the predictive power depends on the extent to which bank liabilities are market traded. [23] conducted a research to use the financial data to identify changes in bank conditions. They used the call-report data to predict deterioration in condition as measured by changes in two main factors. The call report data could be used to construct nonstatistical early-warning models that mimic the examination process. The two main factors are the CAMEL ratings (the CAMEL rating is explained in the next paragraph) and the role of off-site monitoring in the banking examination process. Off-site monitoring is an alternative method for on-site monitoring system in a bank using the financial ratios. There are twenty two commonly used financial ratios selected ${ }^{1}$. Each ratio is included because it provides insight into a dimension of the financial condition of the sample banks that is reflected in the actual composite CAMEL rating. The ratios generally are similar to those used in previous early-warning failure-prediction models. Fifty eight samples of banks in the US were chosen. They used logit regression and logit analysis ratio. They found five financial ratios that are significant as follows:

i- Asset quality : defined as non-performing loans and leases divided by primary capital;

ii- Liquidity-type ratios : loans plus securities/ total sources of funds;

iii- Liquidity-type ratios : volatile liabilities/total sources of funds;

iv- Primary capital/average assets;

v- Current-quarter ratio : nonperforming-loan ratio.

For the Shari'ah compliance, the CAMEL ratings should be assessed. This CAMEL rating consists of Capital adequacy, Asset quality, Management, Earnings and Liquidity Management. [15] stated that the CAMEL ratings generally assess overall soundness of the banks, and identify and/or predict different risk factors that may contribute to turn the banks into a problem or failed banks. These banks tend to perform the FFS. Bangladesh Banks have included an additional key point of "Sensitivity to market risk" to be the CAMELS. However, [15] has recommended the CAMELS Rating Framework to be the CAMELSS in order to comprehend the Islamic Banking that is "Shari'ah Rating".

In line with [15] recommendation on the "Shari'ah Rating" is the Ethical Identity Index (EII). EII is the Shari'ah compliance determination identified by the existence of discrepancy between the communicated (based 
on information disclosed in the annual reports) and ideal (disclosure of information deemed vital based on the Islamic ethical business framework) ethical identities [10]. The function of the SSB is very crucial in determining the EII. IBs are expected to comply with the Shari'ah law in all of their activities in safeguarding the purity of the Islamic law. The authors examined seven Islamic Banks over a three-year period of longitudinal survey in the Arabian Gulf region. They found that six out of seven Islamic Banks suffered from disparity between the "communicated" and "ideal" ethical identities.

From both functions of the CAMELSS and EII, they could ensure the Shari'ah compliance in the IBs. Thus, the FFS detection model in CBs could be applied similarly by adding this Shari'ah compliance control variable.

There are financial ratios specifically meant for IBs due to the nature of the Shari'ah inherent in the Islamic operation. The Shari'ah prohibits interest (riba), uncertainty (gharar) and gambling (maysir). Thus, the IBs are strictly required to comply with the $\mathrm{SAB}$ as to ensure that the trustworthiness of the customers is properly taken care of. Hence, all the Islamic Financial Products have unique risk profile. This gives rise to a number of regulatory issues pertaining to capital adequacy and liquidity requirements [24]. Operational issues also arise as IBs are limited in their choice of risk and liquidity management tools such as derivatives, options and bonds. [24] analysed two IBs in Pakistan regarding the financial contracts, risk and performance. The financial ratios that had been looked into were the Capital Adequacy (Capital/RWA and net worth/total assets), Asset Composition (NPL/gross loans and NNPL/capital), Earning and Profitability (ROA and ROE) and Liquidity (Cash deposit ratio, Liquid assets/total assets and Liquid assets/total deposits). He found that the IBs have shown good performance with respect to the returns on their assets and equity and have also demonstrated better risk management and maintained adequate liquidity [25] made a comparison of liquidity management between the IB (represented by Islami Bank Bangladesh Limited) and CB (represented by AB Bank Limited) in Bangladesh for the period of 2003 to 2006 for both short-term and long-term basis. They found that the IB showed comparatively better performance in liquidity management than the $\mathrm{CB}$ both on short-term and long-term basis. Even though the CBs or IBs are required to monitor and manage its liquidity position effectively and cautiously, this is one of the most critical tasks of the banks [26] evaluated the intertemporal and interbank performance of IB in Malaysia (BIMB) specifically for profitability, liquidity, risk and solvency, and community involvement for the periods of 1984-1997. Financial ratios were applied in measuring these performances. The T-test and F-test were used in determining their significance. The study found that BIMB had relatively more liquidity and was less risky compared to a group of eight CBs.

Literature has found that at any time IBs relatively have more liquidity and are less risky as compared to CBs [26]. However, it does not guarantee that IBs will not be facing a financial distress. Thus, these IBs still need to monitor their performance by way of the financial distress-detection model.

\section{REFERENCES}

[1] S. S. Ali, "Financial Distress and Bank Failure: Lessons from Closure of Ihlas Finans in Turkey," Islamic Economic Studies, vol. 14, no. 1 \& 2, pp. 1-52. 2007

[2] Treadway Commission, Report of the National Commission on Fraudulent Financial Reportin, October 1987

[3] Quran ( Surah al-Nisa 4:29)

[4] P. R. Kumar and V. Ravi, "Bankruptcy Prediction in Banks and Firms via Statistical and Intelligent Techniques - A Review," European Journal of Operation Research, vol. 180, pp. 1-28, 2007

[5] A. I. Qureshi, "Islam and the Theory of Interest," Lahore: Sh. Md. Ashraf, pp. 220, 1946

[6] N. Siddiqi, "Islami Usul par Banking," (Banking according to Islamic principles), Paper in the Urdu monthly Chiragh-e-Rah (Karachi), vol. 1, no. 11\&12 (Nov.\&Dec.), pp.24-28 and 60-64, 1948. Mentioned in Siddiqi 1988.

[7] S. M. Ahmad, Economics of Islam, Lahore: Sh. Muhammad Ashraf, 1952.

[8] A. Y. Mudawi, "Islamic Banks' Problems and Prospect," Paper Presented at the International Seminar on Islamic Banking, Islamabad, 1984.

[9] B. S. Chong and M. H. Liu, "Islamic Banking: Interest-free or interest-based?" Pacific-Basin Finance Journal, vol. 17, pp. 125144, 2009

[10] R. Haniffa and M. Hudaib, "Exploring the Ethical Identity of Islamic Banks via Communication in Annual Reports," Journal of Business Ethics, vol. 76, pp. 97-116, 2007

[11] T. Gambling, R. Jones, and R. A. Karim, "Creditable Organizations: Self Regulation v. External Standard Setting in Islamic Banks and British Charities," Financial Accountability and Management, vol. 9, no. 3, pp. 195-207, 1993

[12] S. A. Mohamed Sultan, "A Mini Guide to Shari'ah Audit for Islamic Financial Institutions," A Premier, Cert Publications, 2009

[13] R. T. Ariss, "Competitive conditions in Islamic and conventional banking: A global perspective," Review of Financial Economics,doi:10.1016/j.rfe.2010.03.002, 2010

[14] R. A. A. Karim, "International accounting harmonization, banking regulation, and Islamic banks," The International Journal of Accounting, vol. 36, no. 2, pp: 169-193, May 2001

[15] A. A. Sarker, "CAMELS Rating System in the Context of Islamic Banking: A Proposed 'S' for Shariah Framework," Journal of Islamic Economics, Banking and Finance, vol. 2, no. 2. pp. 1-26, 2006

[16] Y. Demyanyk and I. Hasan, "Financial Crises and Bank Failures: A review of Prediction Methods," Omega The International Journal of Management Science, vol. 38, pp. 315-324, 2010

[17] A. Demirguc-Kunt and E. Detragiache, "The Determinants of Banking Crises in Developing and Developed countries," IMF Stuff papers, pp.81-109, 1998

[18] D. C. Wheelock and P. W. Wilson, "Why do Banks Disappear? The Determinants of U.S. Bank Failures and Acquisitions," The Review of Economics and Statistics, MIT Press, vol. 82, no. 1, pages 127138, February, 2000

[19] K. Kanagaretnam, C. Y. Lim, and G. J. Lobo, "Auditor reputation and earnings management," International Evidence from the Banking Industry, J. Bank Finance, doi:10.1016/j.jbankfin.2010.02.020, 2010

[20] P. S. Mohanram, "How to Manage Earnings Management?" Accounting World, Institute of Chartered Financial Analyst of India. 2003.

[21] J. Kolari, D. Glennon, H. Shin, and M. Caputo, "Predicting Large US Commercial Bank Failures," Journal of Economics and Business, vol. 54, pp. 361-387, 2002

[22] I. Distinguin, P. Rous, and A. Tarazi, "Market Discipline and the Use of Stock Market Data to Predict Bank Financial Distress," Journal of Financial Services Research, vol. 30, pp. 151-176, 2006

[23] G. Whalen and J. B. Thomson, "Using Financial Data to Identify Changes in Bank Condition," 1988, pp: 17-26 http://clevelandfed.org/research/review/ retrieved on 18 May 2011

[24] A. Siddiqui, "Financial Contracts, Risk and Performance of Islamic Banking," Managerial Finance, vol. 34, no. 10, pp. 680-694, 2008

[25] M. M. Islam and H. A. Chowdhury, "A Comparative Study of Liquidity Management of an Islamic Bank and a Conventional Bank: The Evidence from Bangladesh," Journal of Islamic Economics, Banking and Finance, vol. 5, no. 1, pp. 89-108, 2009

[26] A. Samad and M. K. Hassan, "The Performance of Malaysian Islamic Bank During 1984-1997: an Exploratory Study," International Journal of Islamic Financial Services, vol. 1, no. 3, pp. 1-14, 1999. 


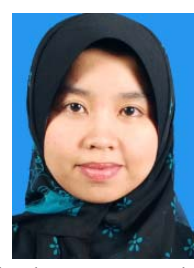

Nurul Husna Haron is a lecturer from Limkokwing University of Creative Technology. She is currently an Associate Research Fellow at Accounting Research Institute. She is a member of WSEAS. She obtained her Master in Accounting from Universiti Teknologi MARA, Malaysia in 2009. Her area of interest is in Forensic Accounting, Islamic Banks, Financial Reporting, Auditing and Zakat. Up to know, she has presented and published more than 5 articles in refereed journals and books.

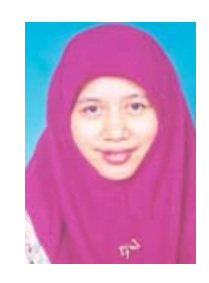

Prof Dr Rashidah Abdul Rahman is a professor in corporate governance and Islamic finance. She is currently the Deputy Director of the Accounting Research Institute (ARI), Faculty of Accountancy, Universiti Teknologi MARA, Shah Alam, Malaysia. With research interest in corporate governance, waqf governance, Islamic finance, intellectual capital, financial reporting, corporate ethics, corporate social responsibility, and mergers and acquisitions, she has presented and published more than 90 articles in refereed journals. She sits on the Editorial Board of Malaysian Accounting Research Journal and has reviewed articles for both local and international journals. She has been an external examiner for post graduate students both at the local universities and abroad. 